\title{
NEVAINĪGUMA PREZUMPCIJA: KAS TĀ IR, KO UN KĀPĒC PAREDZ?
}

\section{PRESUMPTION OF INNOCENCE: WHAT IS IT, WHAT DOES IT DETERMINE, AND WHY?}

\author{
Kristīne Strada-Rozenberga, Dr. iur.
}

Latvijas Universitātes Juridiskās fakultātes

Krimināltiesisko zinātṇu katedras profesore

\section{Summary}

The article deals with the presumption of innocence as one of the basic principles of criminal procedure. It outlines the legal framework of this principle, the current issues, but basically and above all focuses on the question of whether the presumption of innocence is a presumption in the usual sense of the word, what the assumption itself is, and what it really means, and the purpose of this principle. Attention is drawn to the presumption of innocence as a requirement for specific criminal proceedings. Describing the objective of the presumption of innocence, it is agreed that, alongside the protection of the rights of a particular person, this principle is also of a benefit to society as a means of strengthening the rule of law. Analyzing what the presumption of innocence is intended to support, it is agreed that this fundamental principle of criminal procedure implies recognition of the assumption of innocence as opposed to the non-presumption of guilt. It is also acknowledged that in examining the presumption of innocence, it is important that a person cannot be "legally recognized" nor "considered" as guilty until proven guilty according to law. If the first prevents the attribution of legal and other consequences to a person who has not yet been convicted of having committed a criminal offense, the other ensures appropriate treatment of the person during the proceedings.

Atslēgvārdi: nevainīguma prezumpcija, kriminālprocesa pamatprincips, personas tiesības kriminālprocesā, tiesiskuma stiprināšana

Keywords: presumption of innocence, fundamental principle of criminal procedure, rights of a person in criminal proceedings, strengthening of the rule of law

\section{Ievads}

Nevainīguma prezumpcijai ir acīmredzami neapstrīdama loma retorikā, kas ieskauj kriminālprocesu.

(Antony Duff, 2013)

Nevainīguma prezumpcija tiek uzskatīta par vienu no kriminālprocesa pamatprincipiem, kura nepieciešamība ir vispārpieņemta. Bieži vien šis princips tiek uztverts kā pašsaprotams, tai pašā laikā tā dziḷāka analīze nereti izpaliek. Šis 
ir viens no konstitucionāla līmeṇa kriminālprocesa funkcionēšanas principiem, kura tiesiskais regulējums ietverts gan konstitūcijās, gan dažādos starptautiskos un Eiropas Savienības cilvēktiesību dokumentos, gan nacionālajos likumos. Tomēr šì principa izpratnes un būtības skaidrojumā joprojām sastopama nevienprātība, diskusijas un problemātika. Par nevainīguma prezumpciju varētu rakstīt daudz un to aplūkot no dažādiem skatpunktiem. Šajā rakstā ieskicēts nevainīguma prezumpcijas tiesiskā regulējuma modelis un mūsdienu aktualitātes, taču pamatā un galvenokārt uzmanība pievērsta jautājumiem par to, vai nevainīguma prezumpcija vispār ir prezumpcija šì vārda ierastajā izpratnē, kādu pieṇēmumu sevī ietver šis princips un ko tas īsti nozīmē, kā arī kāds ir šì principa mērksis. Uzmanìba pievērsta nevainīguma prezumpcijai kā uz konkrētu kriminālprocesu attiecināmai prasībai. Raksturojot nevainīguma prezumpcijas pastāvēšanas mērḳi, mēgènāts rast skaidrību, vai tā ir tikai konkrētas personas procesuāla garantija vai arī šim principam ir nozīme arī kā sabiedrības labumam - tiesiskuma stiprināšanas līdzeklim. Savukārt, analizējot, ko īsti nevainīguma prezumpcija paredz pien,emt par kriminālprocesa "sākuma punktu", skatīts tas, vai tā ir "nevainīguma" prezumēšana vai vainīguma prezumpcijas neesamība. Tāpat nevainīguma prezumpcijas apskatā izvirzìts jautājums par to, vai nevainīguma prezumpcija liedz "atzît" vai "uzskatīt" personu par vainīgu noziedzīga nodarījuma izdarīšanā, pirms tas nav noticis likumā noteiktā kārtībā, kas l̦auj saskatìt nevainīguma prezumpcijas gan kā procesuāla instrumenta, gan attieksmes formulas būtību. Izvirzìto jautājumu apskatam pētīts gan nevainīguma prezumpcijas normativais regulējums, gan tās skatījums Satversmes tiesas judikatūrā, gan doktrīnā pastāvošās diskusijas un viedokḷu dažādỉba.

\section{Ieskats nevainīguma prezumpcijas kā kriminālprocesa pamatprincipa tiesiskajā regulējumā}

Nevainīguma prezumpcija ir kriminālprocesa princips ar senu vēsturi, kura saistāma vismaz ar Justiniāna laiku un kuras izpētē gan arī nav neskaidru un diskutējamu aspektu. ${ }^{1}$ Lai gan nereti nevainīguma prezumpcijas mūsdienu izpratne tiek saistīta ar angḷ tiesībām, atzīmējams, ka princips "nevainīgs, pirms nav pierādīts, ka vainīgs" angḷu tiesās vai jurisprudences traktātos nav atrodams pirms 1800. gada, kamēr francūži to iekḷāva 1789. gada Franču deklarācijā, nosakot, ka "ikviens cilvēks prezumējams par nevainīgu, kamēr nav atzìts tā vainīgums". ${ }^{2}$

Mūsdienās nevainīguma prezumpcijas tiesiskais regulējums rodams gan konstitūcijās, gan starptautiskajos un Eiropas Savienības normatīvajos dokumentos, gan nacionālā līmeṇa kriminālprocesa tiesībām veltītos normatīvos aktos. Lai nodrošinātu rakstā tālāk apskatīto jautājumu pilnīgāku ilustrāciju, sniedzams ieskats šajos normatīvajos dokumentos, îsi tos citējot un izceḷot šì raksta tematikai atbilstošos formulējumus.

1 Sk. sīkāk, piemēram: Stumer A. The Presumption of Innocence: Evidental and Human Rights Perspectives. UK: Hart Publishing, 2010, p. 1; Van Damme R. The Presumption of Innocence: an Antidote for Sarifal Venom? Patterns of Girard's 'Primiteve' Sacred in Late Medieval and Early Modern Criminal Law. Netherlands Journal of Legal Philosophy, 2016, No. 1 (45), pp. 10-41.

2 Pennington K. Innocent Until Proven Giulty: The Origins of Legal Maxim. 63 JURIST: STUD. CHURCH L. \& MINISTRY, 2013, No. 16, pp. 106-124. 
Konstitucionālā regulējuma līmenī Latvijā nevainīguma prezumpcijas regulējums visai lakoniskā veidā iekḷauts Satversmes" 92. panta otrajā teikumā: "Ikviens uzskatāms par nevainīgu, iekams viṇa vaina nav atzīta saskaṇā ar likumu.” Jautājums par dažādu Latvijas nacionālo likumu normu atbilstību šai Satversmes normai vairākkārt ir nonācis Satversmes tiesas uzmanības lokā, kura savos spriedumos iekḷāvusi nozīmīgas atziņas par nevainīguma prezumpcijas principa saturu un pastāvēšanas mērḳi. Tā Satversmes tiesa atzinusi, ka "nevainīguma prezumpcija pasargā personu, par kuru izteikts pien̦ēmums vai apgalvojums par, iespējams, tās izdarītu noziedzīgu nodarījumu, no atzī̌̌anas par vainīgu, pirms šìs personas vaina nav pierādīta likumā noteiktā kārtībā..." un ka "Nevainīguma prezumpciju veido trīs elementi... 1) tā aizsargā personu, lai to neatzìtu par vainīgu, kamēr tās vaina nav pierādìta saskañā ar likumu, 2) personai nav jāpierāda savs nevainīgums [..], 3) visas saprātīgas šaubas par vainu, kuras nav iespējams novērst, jāvērtēe par labu apsūdzètai personai [..]". 4 Tāpat Satversmes tiesa norādījusi, ka "Nevainīguma prezumpcija liedz pret personu izturēties tā, it kā bütu pierādīts, ka tā izdarījusi noziedzīgu nodarījumu". ${ }^{5}$

Minami vairāki starptautiskā un Eiropas Savienības līmeṇa normatīie dokumenti, kuros iekḷauta nevainīguma prezumpcija.

- Vispārējās cilvēktiesību deklarācijas ${ }^{6} 11$. pants - saskaņā ar to "Katram cilvēkam, kam inkriminèts kriminālnoziegums, ir tiesības tikt uzskatītam par nevainīgu, kamēr viṇa vaina nebūs pierādīta saskaṇā ar likumu atklātā tiesas procesā, kurā viṇam tiek nodrošinātas visas iespējas uz aizstāvību”. (Everyone charged with a penal offence has the right to be presumed innocent until proved guilty according to law in a public trial at which he has had all the guarantees necessary for his defence.)

- Starptautiskā pakta par pilsoniskajām un politiskajām tiesībām7 14. pants tajā paredzēts, ka "Katram, kam inkriminēts kriminālnoziegums, ir tiesības tikt uzskatītam par nevain̄̄gu, kamēr vina vaina nebūs pierādīta saskaṇā ar likumu". (Everyone charged with a criminal offence shall have the right to be presumed innocent until proved guilty according to law.)

- Eiropas Cilvēka tiesību un pamatbrīvību konvencijass ${ }^{8}$ 6. pants - tajā noteikts, ka "Ikviens, kas tiek apsūdzèts kriminālnoziegumā, tiek uzskatìts par nevain̄̄gu, kamēr vina vaina netiek pierādìta saskaṇā ar likumu”. (Everyone charged with a criminal offence shall be presumed innocent until proved guilty according to law.)

- Eiropas Savienības Pamattiesību hartas" 48. pants - saskaņā ar to "Ikvienu apsūdzèto uzskata par nevainīgu, kamēr vaina nav pierādīta saskaṇā ar likumu". (Everyone who has been charged shall be presumed innocent until proved guilty according to law.)

3 Latvijas Republikas Satversme: LV likums. Pieņemts 15.02.1922. [22.03.2019. red.].

4 Sk., piemēram: Satversmes tiesas 23.02.2006. spriedums lietā Nr. 2005-22-01, 4. p. Latvijas Vēstnesis, 2006, Nr. 34 (3402); Satversmes tiesas 15.11.2016. spriedums lietā Nr. 2015-21-01, 19. p. Latvijas Vēstnesis, 2016, Nr. 224 (5796).

5 Satversmes tiesas 23.02.2006. spriedums lietā Nr. 2005-22-01, 5.1. p. Latvijas Vēstnesis, 2006, Nr. 34 (3402).

6 ANO Vispārējā cilvēktiesību deklarācija. Piencemta 10.12.1948.

7 ANO Starptautiskais pakts par pilsoṇu un politiskajām tiesībām. Pieņemts 16.12.1966.

8 Eiropas Cilvēka tiesību un pamatbrīvību konvencija. Parakstīta Romā 04.11.1950.

9 Eiropas Savienības Pamattiesību harta. Eiropas Savienības Oficiālais Vēstnesis, 2012, Nr. C 326. 
- Eiropas Parlamenta un Padomes Direktivas ES 2016/343 (2016. gada 9. marts) par to, lai nostiprinātu konkrētus nevainīguma prezumpcijas aspektus un tiesības piedalīties klātienē lietas izskatīšanā tiesā kriminālprocesā ${ }^{10}$ (turpmāk - ES Nevainīguma prezumpcijas direktīva) 3. pants - tajā noteikts, ka "Dalībvalstis nodrošina, ka aizdomās turētie un apsūdzētie tiek uzskatīti par nevainīgiem, kamēr nav pierādīta vinu vaina saskaņā ar tiesību aktiem”. (Member States shall ensure that suspects and accused persons are presumed innocent until proved guilty according to law.)

Nacionālā līmenī attiecībā uz kriminālprocesu nevainīguma prezumpcija Latvijā nostiprināta Kriminālprocesa likuma ${ }^{11}$ (turpmāk - KPL) 19. pantā, kura pirmajā daḷā noteikts: "Neviena persona netiek uzskatîta par vainīgu, kamēr tās vaina noziedzīga nodarījuma izdarǐšanā netiek konstatēta šajā likumā noteiktajā kārtībā."

\section{Nevainīguma prezumpcija un mūsdienu aktualitātes}

Nevainīguma prezumpcija kā kriminālprocesa princips, lai arī sens un vispāratzìts, tomēr atzīstams par tādu, kas pastāvīgi attīstās. Arī pēdējā desmitgade un turpmākie gadi var tikt attiecīgi vērtēti vai prognozēti kā laiks, kurā notiek pastiprināta pievēršanās nevainīguma prezumpcijai un tās izpratnei uz moderno kriminālprocesa virzienu attīstības fona. Modernie kriminālprocesa attīstības virzieni galvenokārt saistās ar tādu uzdevumu attiecināšanu uz krimināltiesisko sfēru, kas agrāk tai nebija raksturīgi (piemēram, uz notiesāšanu nebalstīta mantas konfiskācija, noziedzīgi iegūtu līdzekḷu legalizācijas izpratnes kardināla pārskatīšana, atbildību nesaistot ar konkrēti izdarìtu noziedzīgu nodarījumu, juridisko personu krimināltiesiska atbildība utt.), kā arī veidiem, kas pat salīdzinoši nesenā pagātnē nebija raksturīgi krimināltiesiskajai sfērai (piemēram, arvien lielāka prezumpciju izmantošana, arvien aktīvākas lomas atvēlēšana privātpersonām pierādīšanā, atsvabinot no pierādīšanas pienākuma valsti utt.).

Šajos apstākḷos jau tagad apzināmas un tuvākajā nākotnē prognozējamas galvenās jomas vai virzieni, kuros nevainīguma prezumpcijas izpratnes un darbības robežu aspekts ir un/vai kḷūs īpaši aktuāls.

- Šķietama "procesuālo tiesību” efektivitātes panākšana ar materiālo tiesību palìdzību, piemēram, konstruējot tādus noziedzīgo nodarījumu sastāvus, kuros paredzēta atbildība bez personas vainīguma izvērtēšanas utt. Šāds aspekts zināmā mērā saistāms ar jau ilgāku laiku pastāvošo diskusiju par to, vai nevainīguma prezumpcijai ir vai nav saskatāms materiāltiesiskais aspekts. ${ }^{12}$ Šì diskusija ir smaga un sarežğìta, to uzskatāmi ilustrē, piemēram, viedoklis, ka nevainīguma prezumpcijai ir procesuāla daba un tā nav attiecināma uz to, kas ir un kas nav atzīstams par sodāmu - tam pretnostatās

10 Eiropas Parlamenta un Padomes Direktīva 2016/343 par to, lai nostiprinātu konkrētus nevainīguma prezumpcijas aspektus un tiesības piedalīties klātienē lietas izskatīšanā tiesā kriminālprocesā. Pienemta 09.03.2016.

11 Kriminālprocesa likums: LV likums. Pieņemts 21.04.2005. [21.03.2019. red.].

12 Šajā rakstā ar "materiāltiesisko" aspektu saprotams iespējamais nevainīguma prezumpcijas aizskārums ar materiālo tiesību normām. Netiek skatīts jautājums par to, vai pašai nevainīguma prezumpcijai nav materiāltiesisku tiesību daba, piemēram, saistībā ar tiesībām uz reputāciju, goda un cieṇas aizsardzību. Caterini M. The Presumption of Innocence in Europe: Developments in Substantive Criminal Law. Beijing Law Review, 2017, Nr. 8, pp. 100-140. 
atzinumi, ka būtu absurdi neuzlikt procesuālo pierādīšanas pienākumu par nevainīgumu, tai pašā laikā neattiecinot nevainīguma prezumpciju uz tā sauktās tiešās atbildības gadījumiem (strict liablity). ${ }^{13}$ Neiedziḷinoties šajā diskusijā dziḷāk, kas izietu ārpus šì raksta tiešā uzdevuma, atzīstams, ka viskorektāk būtu nemēgināt ielikt nevainīguma prezumpciju kādos formālos rāmjos, tādējādi nepamatoti formāli sašaurinot tās darbības robežas, bet, veidojot gan materiālo tiesību normas, gan procesuālās darbības vadlīnijas, respektēt nevainīguma prezumpcijas ideju un tās esamības mērķi.

- Prezumpciju pielietojuma paplašināšana. Tas, ka kriminālprocesā, kurā kā pamatprincips ir nostiprināta nevainīguma prezumpcija, par prettiesisku pati par sevi nav atzīstama fakta legālo prezumpciju pastāvēšana, ir moderna kriminālprocesa neatṇemama sastāvdaḷa. Šo prezumpciju pastāvēšanas pašas par sevi tiesiskumu ir atzinusi gan Eiropas Cilvēktiesību tiesa, ${ }^{14}$ gan ES institūcijas, ${ }^{15}$ vienlaikus strikti norādot, ka šādām prezumpcijām jābūt saprātīgām un samērīgām, atspēkošanai viegli pakḷaujamām, tādējādi to esamība nenonāk pretrunā ar nevainīguma prezumpcijas būtību un pastāvēšanas mērḳi. Fakta legālo prezumpciju piel̦aujamību Latvijas apstākl̦os vērtējusi un tās atzinusi par piel̦aujamām un Satversmē atbilstošām arī Satversmes tiesa, ${ }^{16}$ kura savā spriedumā iekḷāvusi visai kardinālas atziṇas, piemēram, ka, ieviešot fakta legālās prezumpcijas, tiesiski var tikt radīta iespēja uzlikt personām pienākumu "pierādīt savu nevainīgumu". ${ }^{17}$ Domājams, ka ar terminologijas lietošanu būtu jābūt uzmanīgiem, jo kāda fakta izskaidrošana u. tml., kas atsevišķos gadijumos var tikt uzlikta personai, nebūtu pielīdzināma "nevainīguma konkrēta noziedzīga nodarījuma izdarīšanā” pierādīšanai. Atzīstams gan, ka visi Satversmes tiesas spriedumi, kuros nevainīguma prezumpcijas aspekts līdz šim ticis vērtēts, ir attiekušies nevis uz Krimināllikuma vai Kriminālprocesa likuma normām, bet gan uz jautājumiem, kuri Satversmes tiesas ieskatā arī paḳ̣aujami kriminālprocesuālo garantiju regulējuma un lìdz ar to nevainīguma prezumpcijas attiecināmības sfērai.

- Pierādīšanas pienākuma pārnešana un dažādie pierādīšanas standarti (lìmen,i) kriminālprocesāa kā arī līdzdarbošanās pienākums pierādijumu ieguvē. Pierādīšanas pienākuma uzlikšana citiem kriminālprocesa dalībniekiem, izṇemot procesa virzītāju pirmstiesas posmā un apsūdzības uzturētāju iztiesāšanā, arī ir raksturīga mūsdienu kriminālprocesam. Latvijā spēkā esošajā tiesiskajā regulējumā kā centrālais minams KPL 126. pants, tomēr atsevišķas nianses iekḷautas arī citās KPL normās. Nenoliedzot, ka atsevišķos gadījumos uzlikt aktīvu pienākumu līdzdarboties pierādīšanā procesa dalībniekiem ir gan saprātīgi, gan samērīgi un ka tas ir

13 Sk. sīkāk, piemēram: Stumer A. 2010, pp. 53-67.

14 Spilgtākais Eiropas Cilvēktiesību tiesas judikatūras piemērs - 07.10.1988. spriedums lietā Salabiaku pret Franciju (pieteikuma Nr. 10519/83).

15 Sk., piemēram, Eiropas Parlamenta un Padomes Direktīvu 2016/343 par to, lai nostiprinātu konkrētus nevainīguma prezumpcijas aspektus un tiesības piedalīties klātienē lietas izskatīšanā tiesā kriminālprocesā. Pieņemta 09.03.2016.

16 Satversmes tiesas 15.11.2016. spriedums lietā Nr. 2015-21-01, 19. p. Latvijas Vēstnesis, 2016, Nr. 224 (5796); Satversmes tiesas 28.03.2013. spriedums lietā Nr. 2012-15-01, 15.1. p. Latvijas Vēstnesis, 2016, Nr. 224 (5796).

17 Ibid. 
sabiedrības interesēs, tomēr šajā aspektā īpaši svarīgi ir izvērtēt, vai pierādīšanas pienākuma uzlikšana nenonāk pretrunā ar nevainīguma prezumpcijas būtību un pamatfunkciju, tai skaitā ikvienas personas tiesībām uz pašneapsūdzēšanu. ${ }^{18}$

- Nevainīguma prezumpcija un juridiskā persona. Par šì jautājuma problemātiku spilgti liecina, piemēram, tā "apiešana" ES nevainīguma prezumpcijas direktīvā, to uz juridiskās personām neattiecinot un kā pamatojumu šādai rīcíbai norādot - "ņemot vērā valsts tiesību aktu un judikatūras pašreizèjo attīstības pakāpi valstu līmenī un Savienības līmenī, ir pāragri Savienības līmenī pieṇemt tiesību aktus par juridisko personu nevainīguma prezumpciju”. ${ }^{19} \mathrm{Li} d z$ ar to pašlaik nevainīguma prezumpcijas attiecināmība uz juridisko personu vispār un konkrētos tās aspektos risināma, n, emot vērā starptautiskajā un nacionālajā līmenī noteiktās cilvēktiesības. ${ }^{20}$ Prognozējams, ka, palielinoties tādu kriminālprocesu skaitam, kuri vērsti pret juridiskajām personām, tāpat kā daudzveidojoties gadijumiem, kad un kā tas notiek, jautājums par dažādu nevainīguma prezumpcijas aspektu attiecināmību uz juridisko personu tiks aktualizēts un līdz ar to prasīs arī atbilstošus risinājumus vismaz judikatūrā.

Par katru no šiem virzieniem var runāt daudz plašāk, šajā rakstā tie tikai ieskicēti, lai uzskatāmi ilustrētu jautājuma aktualitāti. Šì raksta uzdevums ir cits, tomēr cieši saistīts ar atbilžu meklēšanu uz izvirzītajiem jautājumiem. Proti, lai risinātu ikvienu konkrētu jautājumu vai problēmu, jāsaprot vispārīgais. Šajā gadījumā tā ir pati nevainīguma prezumpcijas būtība un tās pastāvēšanas mērḳis. Tikai tos saprotot, var tikt risināti jau konkrēti jautājumi. Vai nevainīguma prezumpcija ir vai nav attiecināma uz konkrētu jautājumu (jomu), kādā apmērā un ar kādām īpatnībām - uz šiem jautājumiem var atbildēt tikai tad, ja ir sapratne par to, kas tad ìsti ir nevain̄̄guma prezumpcija, ko tā paredz un kāpēc tā nepieciešama. Tieši atbilžu meklēšanai uz šiem jautājumiem veltītas turpmākās raksta sadaḷas. Bez tam, apzinoties raksta ierobežoto apjomu un plašās diskusijas par attiecīgajiem jautājumiem, raksts vērtējams vien kā ievirze šajā fundamentālajā vērtībā, kas raksturo kriminālprocesu. Vienlaikus raksts veidots kā pamudinājums, risinot ikdienas jautājumus un vairāk vai mazāk īslaicīgas un aktuālas problēmas, neieslīgt fragmentārismā un virspusīgumā, aizmirstot par jautājumu pamatbūtību.

\section{Nevainīguma prezumpcija - vai vispār prezumpcija?}

Nevainīguma prezumpcijas kā kriminālprocesa pamatprincipa nosaukumā redzam vārdu "prezumpcija". Tomēr var pievienoties literatūras avotos norādìtajam, kas l̦auj atzīt, ka tā nav uzskatāma par prezumpciju ši vārda ierastajā izpratnē. Proti, prezumpcijas parasti attiecināmas uz situāciju, kad kāds fakts

${ }^{18}$ Sỉkāk sk., piemēram: Strada-Rozenberga K. Nevainīguma prezumpcija - ES minimālie standarti un Latvijas kriminālprocess. Grām.: Konstitucionālās vērtības mūsdienu tiesiskajā telpā I. Rīga: LU Akadēmiskais apgāds, 2016, 194.-205. lpp.; Meikališa Ā., Strada-Rozenberga K. Pārmainu laiks kriminālprocesā turpinās - 2017. gada grozījumi (II). Jurista Vārds, 17.10.2017., Nr. 43 (997), 28.-36. lpp.

${ }^{19}$ Eiropas Parlamenta un Padomes Direktīva 2016/343 par to, lai nostiprinātu konkrētus nevainīguma prezumpcijas aspektus un tiesības piedalīties klātienē lietas izskatîšanā tiesā kriminālprocesā. Pienememta 09.03.2016. 14. apsvērums.

${ }^{20}$ Sīkāk sk.: Strada-Rozenberga K. Juridiskā persona un nevainīguma prezumpcija kriminālprocesā. Grām.: Konstitucionālās vērtỉbas mūsdienu tiesiskajā telpā I, 606.-614. lpp. 
tiek prezumēts kā pastāvošs tāpēc, ka pastāv kāds cits fakts (prezumpcija izriet no citiem, pierādītiem faktiem), vai arī kad atzinums ir pieredzē sakņots, tas ir, prezumpcijas (presumption) nošķiram no vienkāršiem pieņēmumiem (assumption) tieši ar to, ka tās ir balstītas uz faktiem vai pieredzi. Nevainīguma prezumpcija pavisam noteikti tāda nav. Tās piemērošanai nav nepieciešams nekāds cits fakts, tā nav arī balstīta uz pieredzi, bet gan pastāv pati par sevi kā konstituējoša procesuālo kārtību nosakoša vērtība. ${ }^{21}$ Bez tam pati nevainīguma prezumpcija nekādu faktu nenostiprina (tā faktiski neatzīst, ka persona nav vainīga; tas lielākoties nemaz nav kriminālprocesa uzdevums), bet gan tā vairāk ir vadlīnija procesuālās kārtības noteikšanā, proti, pret personu "Jāattiecas kā pret nevainīgu neatkarīgi no personiskā uzskata, kāds izveidojies, līmenī, kādā tas vispār iespējams”. ${ }^{22}$

Jāpiekrīt, ka nevainīguma prezumpcija nav nedz saistīta ar citu faktu pastāvēšanu, nedz pieredzē sakṇota, tādēl tā var tikt atzìta par pretrunīgu principu. ${ }^{23}$ Respektīvi, fakts, ka ir kāds apsūdzētais, pavisam noteikti neḷauj pamatoti pieņemt, ka viņš tiešām nav vainīgs (tātad prezumpcijai nav uz faktiem balstīta pamatojuma). Tāpat arī pieredze nel̦auj atzìt, ka vairumā gadījumu apsūdzētie būtu nevainīgi. Gluži pretēji, absolūtā vairumā gadījumu personas, kuras tiek apsūdzētas, arī tiek atzìtas par vainīgām. Tā, piemēram, Latvijā prokuratūra pēdējos gados nodod iztiesāšanai krimināllietas, kurās apsūdzēti aptuveni 10000 personu, taču no tām attaisnotas tiek ap 100, tātad aptuveni $1 \% .{ }^{24}$ No šì viedokḷa raugoties, nevainīguma prezumpcija "darbojas pret pieredzi un intuīciju" 25 un "tas, ko mēs īstenībā darām kriminālprocesā - ir izlikšanās process, kas ir pretrunā ar mūsu pieredzi, ka persona, kura ir apsūdzēta par nozieguma izdarīšanu, noziegumu nav izdarījusi" ${ }^{26}$

Tādējādi atzīstams, ka nevainīguma prezumpcija ir nevis tipiska prezumpcija, kas balstīta uz faktiem vai pieredzi, bet gan tiesiski nostiprināts pieñēmums, kurš nosaka procesuālās rīcības modeli ši vārda plašākā nozīmē. Jāpiekrīt, ka ir jābūt labiem iemesliem, lai veidotu un tiesiski uzturētu šo fikciju. ${ }^{27} \mathrm{Lìdz}$ ar to nepieciešams saprast, kādi tad ir iemesli nevainīguma prezumpcijas esamībai.

\section{Nevainīguma prezumpcijas saturs, pamats un nepieciešamỉba}

Kā redzams raksta sākumā, gan Satversmē, gan lielākajā daḷā normatīvo aktu nevainīguma prezumpcija definēta visai lakoniski. Jau izvērstāks tās skatījums iekḷauts KPL, kā arī dažādu tiesu judikatūrā. Nevainīguma prezumpcijas

${ }^{21}$ Sīkāk sk., piemēram: Duff A. Who Must Presume Whom to Be Innocent of What? Netherlands Journal of Legal Philosophy, 2013, No. (42) 3, pp. 193-204, 170-192; Weigend T. There is Only One Presumption of Innocence. Netherlands Journal of Legal Philosophy, 2013, No. (42) 3, pp. 193-204, 193-194; Lippke R. L. Taming the Presumption of Innocence. Oxford University Press, 2016, p. 12; Caterini M. 2017, pp. 114-126 u. c.

22 Ferguson P. R. The Presumption of Innocence and its role in the criminal process. Criminal Law Forum, 2016, No. 27, pp. 131-158 (138-139).

${ }^{23}$ De Jong F., Van Lent L. The Presumption of Innocence as a Counterfactual Principle. Utrecht Law Review, 2016, Vol. 12, Issue 1, pp. 31-49.

${ }^{24}$ Sīkāk sk.: Latvijas Republikas Prokuratūras darba rezultāti 2018. gadā. Pieejams: http://prokuratura.lv/ media/Prokuraturas_darba_rezultati_2018.pdf [aplūkots 22.03.2019.].

${ }_{25}$ Weigend T. Assuming that the Defendant in not Guilty: The Presumption of Innocence in the German System of Criminal Justice. Criminal Law and Philosophy, 2014, No. 8 (2), p. 287. Citēts no: De Jong F., Van Lent L. 2016, pp. 32-49.

26 Weigend T. 2013, pp. 193-204, 193-194.

27 Ibid. 
pamatideja slēpjas frāzē, ka ikviens prezumējams par nevainīgu noziedzīga nodarījuma izdarīšanā, kamēr viņa vainīgums nav apstiprināts (noskaidrots) likumā noteiktā kārtībā. Šìs nostādnes tālāka konkretizācija jau saistāma ar pierādī̌sanas pienākuma uzlikšanu apsūdzētājam, pašapsūdzības pienākuma neesamību apsūdzētajam, ${ }^{28}$ šaubu tulkošanu par labu apsūdzētajam utt. Šajā rakstā pamatā uzmanība veltīta tieši šai nevainīguma prezumpcijas pamatidejai, padziḷināti nepievēršoties katram tās elementam. Tās apskatē savukārt var uzdot vairākus nozīmīgus jautājumus, tai skaitā - attiecībā uz ko prezumpcija darbojas, tas ir, kurš uzskatāms par nevainīgu noziedzīga nodarījuma izdarīšanā; kam tā jāievēro; kas tieši jāprezumē un, visbeidzot, kāpēc tas tā jādara.

Atbilde uz pirmo jautājumu - kurš un kam jāprezumē kā noziedzīga nodarījuma izdarī̌̌anā nevainīgs - pamatā saistāma ar to, cik plaši mēs skatām nevainīguma prezumpcijas darbības robežas. Teorijā pazīstama un plaši diskutēta ir Entonija Dafa (Antony Duff) tā sauktā pilsoniskā nevainīguma prezumpcija, proti, nevainīguma prezumpcija kā pilsoniska uzticība, sociāli ètisks princips. E. Dafs izšḳir vairāku veidu prezumpcijas - nevainīguma prezumpciju, kas raksturīga "tiesas procesam", un tādu nevainīguma prezumpciju, kas ir plašāka, attiecas ne tikai uz konkrētu pagātnē notikušu notikumu, bet arī uz nākotnē iespējamiem nodarījumiem ārpus kriminālprocesuālām aktivitātēm kā, piemēram, pārbaudēm lidostās utt. ${ }^{29}$ Lai arī nevar noliegt, ka cieṇpilna izturēšanās pret personu ietver neuzskatī̌̌anu viṇu par noziedznieku arī sadzīviskās attiecībās, tomēr domājams, ka nevainīguma prezumpcijas izpratnē būtu saglabājama tās juridiskā daba, un tā tomēr skatāma kā noteiktus juridiskos procesus raksturojoša prasība. Tāpat jāpiekrìt, ka krimināltiesības fokusējas uz šaurāku morālo aspektu - nevis prezumē, ka persona vispār nav darījusi neko sliktu, bet gan prezumpciju attiecina uz konkrētu gadijumu. ${ }^{30}$

No tā izriet, ka personas, uz kurām nevainīguma prezumpcija attiecināma, būtu tās, pret kurām valstiski ir izteiktas aizdomas par iespējami izdarìtu noziedzīgu nodarījumu. Tādējādi ir atbalstāma nevainīguma prezumpcijas "šaurā izpratne", ${ }^{31}$ attiecinot to uz ierobežotu konkrētā kriminālprocesā iesaistītu personu loku un saistot tās pastāvēšanu ar noteiktu aizdomu izvirzī̌sanas brīdi. Savukārt attiecībā uz literatūrā izteiktām bažām par to, ka šāda pieeja neattiecina nevainīguma prezumpciju uz personām, kurām formāli nav piešķirts attiecīgs kriminālprocesuāls statuss, ${ }^{32}$ var norādīt: gan tiesību doktrīnā, gan judikatūrā (tai skaitā Eiropas Cilvēktiesību tiesas un Latvijas Augstākās tiesas) ir nostiprināta atziṇa, ka personas statuss nosakāms nevis pēc formāliem kritērijiem (ir vai nav lēmums utt.), bet gan izvērtējot faktiskos apstākḷus. ${ }^{33}$

Jautājot, kurš atzīstams par nevainīgu, literatūrā ticis uzdots arī jautājums, vai nevainīguma prezumpcija attiecināma arī uz vainīgajiem. Jāpiekrīt, ka uz šo jautājumu var atbildēt divējādi. Ar “jā” - brīdī, kad tā attiecas uz faktiski nodarījumu izdarījušo personu, kamēr tā nav atzìta par vainīgu juridiski likumā noteiktā

\footnotetext{
${ }^{28}$ Šeit un turpmāk, ja vien netiek speciāli norādīts kas cits, ar apsūdzēto saprotama ikviena persona, kurai ir tiesības uz aizstāvību neatkarīgi no tās procesuālā statusa.

29 Duff A. 2013, pp. 193-204, 170-192.

30 Sk., piemēram: Weigend T. 2013, pp. 193-194; Lippke R. L. 2016, p. 14.

31 Weigend T. 2013, pp. 193-204, 198.

32 Duff A. 2013, pp. 193-204, 170-192.

33 Sk., piemēram, Augstākās tiesas 30.05.2017. lēmumu krimināllietā Nr. 15830000615 (SKK-60/2017).
} 
kārtībā. Un "nē" - brīdī, kad persona atzìta par vainīgu tiesiskā cel̦ā. ${ }^{34}$ Tomēr uz šo jautājumu var paskatīties arī no cita skatpunkta - piemēram, vai nevainīguma prezumpcija vai vismaz atsevišḳi tās struktūrelementi (labvēlīga attieksme, pierādī̌anas pienākums, šaubu tulkošana par labu apsūdzētajam) nav attiecināmi arī uz citiem krimināltiesiski izlemjamiem jautājumiem, ne tikai uz to, vai persona ir vai nav izdarījusi kriminālsodāmu nodarījumu (tas ir, uz kriminālprocesā atrisināmo pamatjautājumu), piemēram, soda noteikšanas jomu. Šis jautājums nav viennozīmīgi atbildams un, domājams, ir viens no tiem, kam jau tuvākajā nākotnē tiks pievērsta pastiprināta uzmanība. Nav pamata neatbalstīt literatūrā izteikto priekšlikumu ar nevainīguma prezumpciju noteikto attieksmi attiecināt arī uz sodu noteikšanas jomu, kā izpausmi minot - labāk sodīt ar mazāku sodu nekā ar lielāku. ${ }^{35}$ Tādējādi, piemēram, personai pašai nebūtu jāpierāda, ka tai piemērojams iespējami vieglākais sods, tāpat visas šaubas, kas rodas situācijā, kad jāizšķiras par soda bardzību, būtu tulkojamas par labu personai, kurai sods tiek noteikts, u. tml. Katrā ziņā tas būtu attiecināms uz pamatsodu noteikšanu. Tomēr visu nevainīguma prezumpcijas elementu attiecināšana uz visiem krimināltiesiski risināmiem jautājumiem, kas izriet no personas atzīšanas par vainojamu kāda noziedzīga nodarījuma izdarīšanā, iespējams, būtu pārsteidzīga un pārspīlēta. Tà, piemēram, Krimināllikumā ${ }^{36}$ (turpmāk - KL) paredzētie tā sauktie mantas īpašās konfiskācijas gadījumi ne vienmēr atbildīs nevainīguma prezumpcijas piemērošanas sfērai. Attiecībā uz tā saukto prezumēto noziedzīgi iegūto mantu (sk. KL 70. ${ }^{11}$ p. 2. un 3. daḷu) pierādīšanas pienākums pie noteiktiem priekšnoteikumiem gulstas uz personu, kura apgalvo, ka mantai ir likumīga izcelsme. Tādējādi ir izveidota fakta legālā prezumpcija, kurai ir skaidri piemērošanas priekšnoteikumi un kura, vispārīgi vērtējot, domājams, ir samērīga un legitīma. Tomēr jāatceras, ka šis gadījums tā sauktā prezumētās noziedzīgi iegūtās mantas konfiskācija - lai gan ir saistīts (jo ir izrietošs) ar kādas personas atzišsanu par vainīgu noziedzīga nodarījuma izdarīšanā, tomēr nav viens un tas pats, tas ir, kādas personas rīcībā esošas mantas atzǐšana par noziedzīgi iegūtu vienlaikus nenozīmē personas atzīšanu par vainīgu konkrēta nodarījuma izdarīšanā, līdz ar to, domājams, iziet ārpus klasiskās nevainīguma prezumpcijas piemērošanas robežām. Atzīstams gan, ka šis jautājums nav viennozīmīgi atbildams, un arī šeit sniegtā ievirze ir tikai aicinājums uz diskusiju.

Visbeidzot, kādam var rasties jautājums - ja jau ikviens ir prezumējams kā nevainīgs kriminālsodāma nodarījuma izdarī̌sanā, tad vai ar nevainīguma prezumpciju pretrunā nenonāk pati atzīšana par aizdomās turēto vai apsūdzēto, kas nenoliedzami saistīta ar juridiski noformèta pieṇēmuma izteikšanu par personas iespējamo vainīgumu. Jāpiekrīt, ka ne, jo abi šie aspekti pastāv vienlaikus - tieši atzīšana par aizdomās turēto vai apsūdzēto rada pamatu piemērot nevainīguma prezumpciju, ${ }^{37}$ un ka nevainīguma prezumpcija ir sākotnējs pieņēmums, kas nav galīgs, tas ir pārbaudāms un, iespējams, apgāžams kriminālprocesa laikā. Kā tāda nevainīguma prezumpcija pieprasa atbildīgajām amatpersonām rīkoties tā, "it kā" persona būtu nevainīga. Šajā izpratnē nevainīguma prezumpcija ir simbiotiska ar pien̦ēmumu par personas vainīgumu, kas tiek izteikts, piešķirot tai noteiktu

\footnotetext{
${ }^{34}$ Tomlin P. Could the Presumption of Innocence Protect the Quilty? Criminal Law and Philosophy, 2014, No. 8, pp. 431-447.

35 Ibid.

36 Kriminālprocesa likums: LV likums. Pieņemts 17.06.1998. [21.03.2019. red.].

37 Weigend T. 2013, pp. 198.
} 
statusu. ${ }^{38}$ Tieši šādā gaismā būtu skatāms arī jautājums par dažādu piespiedu līdzekḷu pielietojumu procesa gaitā. Proti, to piemērošana pati par sevi nenonāk pretrunā ar nevainīguma prezumpciju, jo faktiski tie ir līdzekḷi, kas nevis tiek piemēroti tāpēc, ka persona ir vainīga, bet gan kas nepieciešami, lai noskaidrotu, vai persona ir vai nav vainīga. Šim nolūkam noteiktos gadijjumos jānodrošina vinas klātbūtne. ${ }^{39}$

Nākamais jautājums, kas izvirzāms nevainīguma prezumpcijas apskatā, ir tas, kam nevainīguma prezumpcija ir saistoša - proti, kurām personām uzlikts pienākums uzskatìt/neatzìt personu par vainīgu, pirms tas nav noticis likumā noteiktā kārtībā. Izrietoši no piekrišanas skatīt nevainīguma prezumpciju kā uz konkrētu procesu attiecināmu prasību atzīstams, ka šis pienākums attiecināms pamatā uz amatpersonām, kuras iesaistītas kriminālprocesā, kurā tiek lemts jautājums par konkrētas personas vainīgumu. Tāpat šāds pienākums attiecināms arī uz amatpersonām, kuras, lai gan nav konkrētā kriminālprocesa veicēji, var ietekmēt procesu veicošās amatpersonas vai arī veidot nepamatotu sabiedrisko viedokli. ${ }^{40}$ Jāatzīst gan, ka sabiedriskā viedokḷa veidošanā nozīme ir arī citām personām, piemēram, masu mediju pārstāvjiem utt., tomēr to darbība iziet ārpus tās nevainīguma prezumpcijas darbības sfēras, kura apskatīta šajā rakstā. ${ }^{41}$

Nākamais apskatāmais jautājums ir - kas tieši jāprezumē, proti, ko īsti nozīmēe, ka persona prezumējama kā nevainīga noziedzīga nodarījuma izdarīšanā.

Pirmām kārtām var tikt izvirzìts jautājums - kas īsti ir jāpieņem? Ir skaidrs, ka nevar tikt pieṇemts (prezumēts) vainīgums, tas ir, vainīguma prezumpcija (presumption of guilt) ir izslēdzama. Tomēr paliek divas citas iespējas - neprezumēts vainīgums (nonpresumption of guilt) un prezumèts nevainīgums (presumption of innocence). Neiedziḷinoties šo formulējumu būtībā, var šksist, ka nav būtiskas atšķirības. Taču, kā, piemēram, raksta Ričards L. Lipke (Richard L. Lippke), viens no autoriem pēdējo gadu plašākajiem pētījumiem par nevainīguma prezumpciju, jautājums, kurš pamudinājis viṇu rakstīt šo grāmatu, bijis tieši tas, vai ir atšḳirība starp nevainīguma prezumpciju (presumption of innocence) un vainīguma prezumpcijas neesamību (nonpresumption of guilt). ${ }^{42}$ Un tiešām, kaut nedaudz padomājot, redzam, ka atškirìiba ir būtiska. Ja vainīguma prezumpcijas neesamìba

38 De Jong F., Van Lent L. 2016, p. 41.

39 Sk., piemēram: Weigend T. 2013, pp. 193-204, 198; Lippke R. L. 2016, pp. 155-176.

40 Sk., piemēram, Eiropas Parlamenta un Padomes Direktīvu 2016/343 par to, lai nostiprinātu konkrētus nevainīguma prezumpcijas aspektus un tiesības piedalīties klātienē lietas izskatīšanā tiesā kriminālprocesā. Pieņemta 09.03.2016., arī KPL 19. panta 4. daļu, ar kuru KPL papildināts, ieviešot minēto direktīvu - "Ja valsts amatpersona, kas nav kriminālprocesā iesaistītā persona, ar publisku paziņojumu ir izteikusies par personas vainīgumu, pārkāpjot nevainīguma prezumpciju, procesa virzītājs, pamatojoties uz personas motivētu iesniegumu, publiski informē par nevainīguma prezumpcijas principa pārkāpumu, bet iesnieguma kopiju nosūta izvērtēšanai institūcijai, kura var lemt par amatpersonas atbildibu."

${ }^{41}$ Par sabiedrisko viedokli un nevainīguma prezumpciju sīkāk sk. K. Stradas-Rozenbergas rakstu "Sabiedriskais viedoklis un tiesas spriešana - savstarpējās ietekmes tiesiski aktuālie aspekti. Nevainīguma prezumpcijas un tiesas atklātuma principu nozīme, evolūcija un problemātika”. Raksts tapis, pamatojoties uz referātu "Sabiedriskais viedoklis un tiesas spriešana - savstarpējās ietekmes tiesiski aktuālie aspekti. Nevainīguma prezumpcijas un tiesas atklātuma principu nozīme, evolūcija un problemātika”. Referāts prezentēts 2018. gada 26. janvārī konferencē "Sabiedriskā viedokḷa ietekme uz tiesnešiem un tiesu sistēmu kopumā” Latvijas Universitātes Juridiskajā fakultātē. Raksts iesniegts un pieņemts publicēšanai monogrāfijā par sabiedriskā viedokḷa ietekmi uz tiesas spriešanu, kura, domājams, tiks publicēta 2019. gada otrajā pusē.

42 Lippke R. L. 2016, p. vii. 
(vainīguma ne-prezumpcija) kā sākumpunktu paredz arī neitrālu pieeju (t. s. balta lapa), tad nevainīguma prezumēšanas prasība norāda uz nepieciešamību prezumēt cilvēku kā nevainīgu noziedzīga nodarījuma izdarīšanā, nevis kā tikpat iespējami vainīgu kā nevainīgu.

Šai sakarā interesanti norādīt, ka atrodami vairāki zinātniski pētījumi par patieso kriminālprocesā iesaistīto personu attieksmi pret apsūdzēto procesa laikā. Viens no pēdējiem - eksperimentāls pētījums par to, kāda īsti ir attieksme pret iespējamo vainīgumu vai nevainīgumu zvērinātajiem (diemžēl līdz raksta tapšanas brīdim nav izdevies atrast šādus pētījumus par profesionāliem tiesnešiem). Rezultāts - aptuveni 50\%, tātad attieksme - varbūt apsūdzētais ir, bet varbūt arī nav vainīgs. Autori uzsver, ka šāda attieksme, iespējams, nav vispārējā tiesvedību pieredzē nepamatota - tiešām gandrīz 90\% no federālajiem kriminālprocesiem noslēdzas ar spriedumu, kurā apsūdzētais atzīts par vainīgu, tomēr tas, iespējams, ir pretrunā ar to, ko paredz juridiskā doktrīna. ${ }^{43}$ Aspektam, ka pieredze nav pamatojums nevainīguma prezumpcijas esamībai kā tādai, jau pievērsta uzmanība šì raksta sākuma daḷā. Gluži tāpat tā nevar tikt atzīta par pietiekamu neitrālas pieejas ("baltas lapas") pamatošanai. Kā pamatoti norāda R. L. Lipke, "Ja baltas lapas princips vēl varētu tikt attiecināts pret sabiedrības locekḷiem, kas nav iesaistīti kriminālprocesā, tad tas neveicina valsts amatpersonu uztveri vai attiekšanos pret apsūdzēto kā nevainīgu". ${ }^{4}$ Tādējādi atzīstams, ka nevainīguma prezumpcija nav vainas prezumpcijas neesamība, bet gan paredz prezumēt personas nevainīgumu kriminālsodāma nodarījuma izdarī̌sanā.

Vairākos avotos izvērsta diskusija par to, vai prezumējamais nevainīgums noziedzīga nodarījuma izdarīšanā ir materiāls (material innocence) vai pierādītais/ juridiskais (probative innocence), ${ }^{45}$ ar materiālo nevainīgumu saprotot to, ka persona nav izdarījusi kriminālsodāmu nodarījumu, savukārt ar pierādīto nevainīgumu - to, ka tās vaina vēl nav pierādīta likumā noteiktā kārtībā. Neiedziḷinoties izvirzìto diskusiju plašā atspogulojumā, domājams, var piekrist R. L. Lipkem, kurš norāda, ka nevainīguma prezumpcijas kā kriminālprocesa pamatprincipa būtībai vairāk atbilst tā sauktā materiālā nevainīguma prezumēšana, tas ir, pieņemams, ka persona nav izdarījusi kriminālsodāmu nodarījumu. Tikai tā sauktā pierādītā nevainīguma prezumēšana nesasniegtu nevainīguma prezumpcijas mērķi, jo faktiski atkārtotu acīmredzamo - to, ka par pierādīti nevainīgu noziedzīga nodarījuma izdarīšanā uzskatāms tas, kura vainīgums nav pierādīts. Faktiski, šādā veidā interpretējot nevainīguma prezumpciju, tā varētu tikt vērtēta kā "piektais ritenis". 46

Secīgi varam nonākt līdz pēdējam jautājumam - kāpēc nevainīguma prezumpcija ir vajadzīga. Atbildē uz šo jautājumu pilnībā var pievienoties viedoklim, ka nevainīguma prezumpcijas pastāvēšana nepieciešama divu vienādi nozīmīgu interešu dēḷ - tā ir tiesiskuma stiprināšana un konkrētu personu aizsardzība. ${ }^{47}$ Abi šie aspekti pelnījuši nedaudz paplašinātu apskatu raksta noslēgumā.

\footnotetext{
${ }^{43}$ Scurich N., Nguyen K. D., John R. S. Quantifying the presumption of innocence. Law, Probability and Risk, 2016, No. 15, pp. 71-86.

${ }^{44}$ Lippke R. L. 2016, p. 16.

${ }^{45}$ Diskusijas apskatu sk., piemēram, ibid., pp. 14-15.

46 Ibid., pp. 15-16.

47 Stumer A. 2010, p. 27.
} 


\section{Nevainīguma prezumpcija kā kriminālprocesa pamatprincips personas tiesību un interešu aizsardzībai}

Nevainīguma prezumpcija nozīmē procesuālu garantiju personai, par kuru izteikts pieñēmums, ka tā izdarījusi noziedzịgu nodarījumu, un tā atzīta ikvienā pētījumā, kurš veltīts šim tematam. Cieši kopā nevainīguma prezumpcijas kā procesuālas garantijas institūtā faktiski ir savijušies divi aspekti - instrumentālā vērtība un attieksmes formula. Tā pirmais vērsts uz galveno mērḳi - pasargāt noziedzīgu nodarījumu neizdarījušo personu no nepamatotas atzīšanas par vainīgu (izmantojot latviešu valodas vārdus, tas vairāk saistās ar "atzī̌sanu” par vainīgu), tai skaitā nosakot pierādīšanas pienākumu apsūdzētājam, paredzot prasību izslēgt šaubas par personas vainīgumu u. tml. Savukārt otrais nodrošina pienācīgu apiešanos ar personu procesa laikā (vairāk saistāms ar "uzskatīšanu" par nevainīgu).

Lai cik spēcīga būtu procesuālo garantiju sistēma, arī to piemērojot var notiesāt nevainīgo, ${ }^{48}$ tomēr ir jādara viss, lai šādu iespējamību samazinātu līdz minimumam. Kā spēcīga procesuāla garantija nevainīguma prezumpcija nenoliedzami ir taisnīga procesa prasības sastāvdaḷa. Jāpiekrīt, ka bez nevainīguma prezumpcijas šo aizsardzību nodrošina vēl arī citas tiesiska kriminālprocesa prasības, kā, piemēram, tiesības zināt, par ko personu tur aizdomās vai apsūdz, tiesības iesniegt pierādījumus, tiesības uz nopratināšanu utt. ${ }^{49}$ Tomēr nevainīguma prezumpcijai ir savi specifiski uzdevumi.

Nevainīguma prezumpcija nodrošina gan personas pārsteidzīgu neatzīšanu par vainīgu, gan aizsardzību pret nepamatota spēka pielietošanu, gan arī atbilstošu apiešanos ar personu procesa laikā. ${ }^{50}$

Tā tikai nevainīguma prezumpcijai atbilstoša pieeja spēj nodrošināt to, ka persona tiek atzìta par vainīgu nevis tikai tāpēc, ka tikusi apsūdzēta (balstoties uz pieredzi, ka vairums apsūdzēto ir vainīgi), bet gan rūpīgi izvērtējot un pievēršot uzmanību visiem pierādījumiem. Kā pamatoti, atsaucoties uz visiem zināmo Franca Kafkas (Franz Kafka) darbu "Process", saka Endrjū Stamers (Andrew Stumer): “Tas, ka kāds varētu tikt notiesāts, tikai pamatojoties uz to, ka ir apsūdzēts, ir kriminālās justīcijas nakts murga l̦aunākais scenārijs." ${ }^{51}$ Nevainīguma prezumpcija šajā sakarā neprasa neiespējamo - tā neprasa ticēt, ka persona patiešām ir nevainīga noziedzịga nodarījuma izdarīšanā, jo ticēšana nav nekas tāds, ko var ietekmēt ar likumu. Tiek prasīts skatīt izvirzìto jautājumu noteiktā veidā, izvērtēt pierādījumus no šāda skatpunkta. ${ }^{52}$

Jāpiekrīt, ka nevainīguma prezumpcijai ir būtiska funkcija - aizsardzība pret pārmērīgu varas izmantošanu. Kombinācija, kad cilvēkam ir pazemināts sociālais statuss un iespējamība pret viṇu piemērot spēcīgus iejaukšanās līdzekḷus no valsts puses, nostāda apsūdzēto neaizsargātā situācijā. Ir reāla iespējamība, ka valsts izmantos savas plašās procesuālās pilnvaras ar nolūku sākt personu sodīt par noziegumu, kurā viņa tiek turēta aizdomās, pamatojoties uz vispārīgu pieredzi, ka vairums no tiem, ko tur aizdomās, tiešām ir izdarījuši noziedzīgu nodarījumu. Šis pats apstāklis var būt par pamatu valsts pārstāvjiem steigties atzìt vainīgumu bez

\footnotetext{
48 Stumer A. 2010, p. 32.

49 Ibid., p. 33.

50 De Jong F., Van Lent L. 2016, pp. 31-49.

51 Stumer A. 2010, p. 35.

${ }^{52}$ Lippke R. L. 2016, p. 13.
} 
pienācīgas pierādījumu izvērtēšanas. ${ }^{53}$ Tieši pierādīšanas pienākuma uzlikšana apsūdzētājam nodrošina to, ka maksimāli tiek izslēgta nevainīgu personu notiesāšana. Kā pamatoti norāda E. Stamers, pierādīšanas pienākuma attiecināšana uz apsūdzību ir pamatota pirmām kārtām ar to, ka apsūdzībai pieejami lielāki resursi (līdzekḷi pierādījumu iegūšanai). Bet pat tad, ja tiktu nodrošināta vienāda resursu pieejamība, pierādīšanas pienākuma attiecināšana uz apsūdzību vienalga būtu atzīstama par pamatotu. Te jāṇem vērā: lai arī var šḳist, ka apsūdzētais ir ērtākā situācijā, jo viņam tieši ir zināmi fakti par notikušo, faktu zināšana un to pierādīšana nav uzskatāma par vienu un to pašu. Tāpat pierādīšanas pienākuma uzlikšana apsūdzībai ir kā nepieciešams pretspars tendencei neticēt apsūdzētā sniegtajiem pierādījumiem (tai skaitā viṇa liecībai), tāpēc ka viṇam var būt vēlme izvairīties no atzī̌sanas par vainīgu un/vai sodīšanas, tāpat kā izdarīt pāragrus secinājumus par personas iespējamo vainīgumu tikai no tā, ka viṇa ir apsūdzēta. ${ }^{54}$

Ja iepriekš teiktais vairāk attiecināms uz nevainīguma prezumpcijas instrumentālo vērtību (kaut gan ne tikai, jo atsevišķ̧os gadījumos tā cieši savijusies ar attieksmes formulu), tad l̦oti uzskatāmi nevainīguma prezumpcija kā attieksmes formula izpaužas tieši prasībā nevis pieņemt, ka persona vienlīdz iespējami ir vainīga kā nav, bet gan prasībā to prezumēt kā nevainīgu noziedzīgā nodarījuma izdarīšanā, ko uzskatāmi paudis arī E. Dafs, rakstot: laikā, kad noziedznieki regulāri masu medijos tiek demonizēti, dažus parādot kā morālus monstrus, kuri, lai sasniegtu savas vēlmes un vajadzības, neapstāsies nekā priekšā, šķiet, nepieciešamas nopietnākas zāles nekā tikai mudinājumi neizdarìt secinājumus par mūsu lìdzcilvēkiem. Tikai apiešanās ar aizdomās turēto vai apsūdzēto kā nevainīgu var novērst kḷūdainos notiesājošos spriedumus situācijā, kad sabiedrība tiek novesta gandrīz histērijā saistībā ar noziegumiem un tiem, kuri, kā tā tic, ir tos izdarījuši. ${ }^{55}$

\section{Nevainīguma prezumpcija un tiesiskuma stiprināšana jeb nevainīguma prezumpcijas ievērošana kā sabiedriska interese}

Tiesiskuma stiprināšanā nevainīguma prezumpcijai ir būtiska loma, jo tā veidota, lai nodrošinātu sabiedrības uzticību krimināltiesiskajai sistēmai - tam, ka par vainīgiem tiek atzìti un izrietoši arī sodīti tikai tie, par ko ir augsti pamatota pārliecība, ka viṇi tiešām ir izdarījuši noziedzīgu nodarījumu. ${ }^{56}$ Jāpiekrīt, ka, no šāda skatpunkta raugoties, ieguvējs no nevainīguma prezumpcijas bezierunu atzīšanas nav tikai persona, kura iesaistīta konkrētā kriminālprocesā un par kuru izteikts pieņēmums, ka tā, iespējams, izdarījusi noziedzīgu nodarījumu, bet gan ikviens sabiedrības loceklis. Jo tikai apstākḷos, kad personu par vainīgu var atzìt situācijā, kad tās vainīgumam ir iegūti pietiekami pierādījumi, tas apstiprināts likumā noteiktā kārtībā procesa laikā, kas atbilst tiesiska procesa prasībām, ikviens var būt tiesiski drošs. Šì tiesiskā drošỉba attiecināma gan uz drošību, ka arī viņš var rēḳināties ar šādu attieksmi situācijā, ja tiktu iesaistīts kriminālprocesā, gan arī uz to, ka viņš, izvēloties apiešanās modeli ar kādu valstiski par vainīgu noziedzīga nodarījuma izdarī̌sanā atzìtu personu (nodarbinātības jomā, sociālā saskarsmē utt.), var pal̦auties, ka šì persona tiešām ir izdarījusi noziedzīgu

\footnotetext{
${ }^{53}$ Weigend T. 2013, pp. 193-204, 196; arī Weigend T. 2014, pp. 285-299 (287).

54 Stumer A. 2010, pp. 34-35.

55 Lippke R. L. 2016, p. 234.

56 Stumer A. 2010, pp. 37-40.
} 
nodarījumu, ja jau valsts to ir atzinusi. Atkāpšanās no nevainīguma prezumpcijas vai tās izpausmju būtiska samazināšana, ieskaitot pierādītības prasību samazināšanu, rada būtisku risku, ka smagās un personu dzīvi dažnedažādos veidos ietekmējošās krimināltiesiskās sekas var tikt attiecinātas uz personu, kura nemaz nav izdarījusi noziedzìgu nodarījumu. Tas savukārt var novest nevis pie tiesiskuma stiprināšanas (kā dažkārt dzirdēts politiķu u. c. personu teiktajā), bet gluži pretēji - paša tiesiskuma un izrietoši uzticības tiesiskumam mazināšanas. Tieši šì iemesla dēḷ nevainīguma prezumpcija nevar tikt skatīta kā tikai konkrētam indivīdam piemītoša tiesība vai interese, kas pretnostatīta sabiedrības vajadzībām. Ikkatrai sabiedrībai ir tiesiska interese, lai atbildība par likuma pārkāpšanu iestājas tam, kurš šo likumu tiešām ir pārkāpis. Vēršanās pret tiem, kuru darbībās vai bezdarbībā nav likuma pārkāpuma, nav tikai šo personu tiesību pārkāpums, bet nenodrošina arī sabiedrības interešu ievērošanu.

Nevainīguma prezumpcijas kā sabiedriskas vērtības pastāvēšana uzliek valstij arī tādus pienākumus, kas nav konkrēti procesuāli, bet gan vispārīga rakstura. Kā spilgtu piemēru tam var minēt, piemēram, iesaistīto personu apmācību. Jo bieži izplatītas kḷūdas (piemēram, ekspertīžu noteikšanā, to rezultātu izmantošanā, nepareizā aculiecinieku apzināšanā, personu nopratināšanā vai tml.), kuras noved pie nepatiesām apsūdzībām un, iespējams, notiesāšanām, ir tieši saistìtas ar nevainīguma prezumpcijas pārkāpšanu. Tas savukārt ir apstāklis, uz ko valsts nevar nereagèt. ${ }^{57}$

Arī noslēdzot šo rakstu ar daudzkārt lietoto teicienu "labāk 100 vainīgie attaisnoti nekā viens nevainīgais notiesāts", kura izcelsme meklējama Justiniāna digestās "labāk vainīgas personas izdarìts noziegums paliek nesodìts nekā nevainīga persona tiek nosodīta", ${ }^{58}$ - var uzskatāmi atzìt nevainīguma prezumpcijas pastāvēšanas mērḳa divējādo dabu: aizsargāt gan cilvēku, gan sabiedrību. Protams, ikvienam, kurš nav izdarījis noziedzīgu nodarījumu, vislielākā interese ir tikt attaisnotam. Tai pašā laikā viņam personiski ir vienalga, vai un cik daudzi citi tikuši notiesāti pareizi. Vismazākais, kas personai šajā brīdī rūp, ir statistikā sakņota pieredze, ka vairums apsūdzēto tiešām bijuši vainīgi. Viṇš vēlas baudīt nevainīguma prezumpciju pilnā apmērā un personīgi. Savukārt arī sabiedrība iegūst no attieksmes, ka labāk piel̦aut kḷūdu, attaisnojot vainīgo nekā notiesājot nevainīgo, jo tikai šāda attieksme raksturo sabiedrību, kurā valda cieņa pret līdzcilvēku, kā arī pārliecība, ka būtiskās krimināltiesiskās sekas pret personu tiks attiecinātas tikai tad, ja būs droša pārliecība, ka persona noziedzīgu nodarījumu izdarījusi. Runa šeit nav par proporciju 100 pret viens, 10 pret viens vai citu - šis ir jautājums par toleranci pret valsts varas vēršanu pret personām, kuras nav izdarījušas kriminālsodāmas darbības.

\section{Kopsavilkums}

1. Nevainīguma prezumpcija ir viens no fundamentāliem kriminālprocesa pamatprincipiem, tās tiesiskais regulējums ietverts gan Satversmē, gan starptautiskos un Eiropas Savienības normatīvos aktos, gan Kriminālprocesa likumā.

\footnotetext{
57 Lippke R. L. 2016, p. 234.

58 Citēts pēc: Stumer A. 2010, p. 2.
} 
2. Nevainīguma prezumpcijas tiesisko regulējumu un attīstību nenoliedzami ietekmē kopējās kriminālprocesa attīstības tendences. Tomēr konkrētu jautājumu lemšanā nevar aizmirst par nevainīguma prezumpcijas būtību. Vai nevainīguma prezumpcija ir attiecināma vai nav attiecināma uz konkrētu jautājumu (jomu), kādā apmērā un ar kādām īpatnībām - uz šiem jautājumiem var atbildēt tikai tad, ja ir sapratne par to, kas īsti ir nevainīguma prezumpcija, ko tā paredz un kāpēc tā nepieciešama.

3. Nevainīguma prezumpcija ir nevis tipiska prezumpcija, kas balstīta uz faktiem vai pieredzi, bet gan tiesiski nostiprināts pieṇēmums, kurš nosaka modeli procesuālajai rīcībai šì vārda plašākā nozīmē.

4. Nevainīguma prezumpcija skatāma kā krimināltiesiskai sfērai raksturīgs princips. Tā attiecināma uz kriminālprocesā risināmo pamatjautājumu - ir vai nav persona vainojama kriminālsodāma nodarījuma izdarīšanā. Uz jautājumiem, kas izriet no personas atzī̌sanas par vainojamu (krimināltiesiskajām sekām), nevainīguma prezumpcija vai kāds tās elements var arī netikt attiecināts. Pēdējais jautājums gan pelnījis plašāku analīzi un izvērtējumu.

5. Nevainīguma prezumpcija paredz kā pieņēmumu personas nevainīgumu, nevis vienādojama ar vainas prezumpcijas neesamỉbu.

6. Nevainīguma prezumpcija nodrošina gan to, ka, pirms vainīgums nav konstatēts likumā noteiktā kārtībā, persona netiek nedz atzīta, nedz uzskatīta par vainīgu. Kamēr pirmais nodrošina tiesisku un citu seku pāragru neattiecināšanu pret personu, otrais gādā par atbilstošu attieksmi pret personu procesa laikā.

7. Nevainīguma prezumpcijas pastāvēšanas nepieciešamība saistāma gan ar konkrētas personas tiesību aizsardzību, gan ar sabiedriskā labuma nodrošināšanu - tiesiskuma stiprināšanu. Personas atzī̌̌ana par vainīgu ārpus likumā noteiktās kārtības, tāpat kā tās uzskatīšana par vainīgu, līdz ar to apiešanās ar viṇu kā vainīgu pirms vainas atzīšanas likumā noteiktā kārtỉbā gan būtiski pārkāpj konkrētās personas tiesības, gan grauj sabiedrības uzticību tiesiskuma nodrošināšanai. 